\title{
Thiobacillus prosperus sp. nov., represents a new group of halotolerant metal-mobilizing bacteria isolated from a marine geothermal field
}

\author{
Harald Huber and Karl O. Stetter \\ Lehrstuhl für Mikrobiologie, Universität Regensburg, D-8400 Regensburg, Federal Republic of Germany
}

\begin{abstract}
From the shallow geothermally heated seafloor at the beach of Porto di Levante (Vulcano, Italy) 8 strains of long, tiny rods were isolated, which represent the first marine metal-mobilizing bacteria. Cells are Gram negative. They grow in a temperature range between 23 and $41^{\circ} \mathrm{C}$ with an optimum around $37^{\circ} \mathrm{C}$ at a salt concentration of up to $6.0 \% \mathrm{NaCl}$. The isolates are obligately chemolithotrophic, acidophilic aerobes which use sulfidic ores, elemental sulfur or ferrous iron as energy sources and procedure sulfuric acid. They show an upper pH-limit of growth at around 4.5. The $\mathrm{G}+\mathrm{C}$ content of their DNA is around $64 \mathrm{~mol} \%$. Based on the results of the DNA-DNA hybridization they represent a new group within the genus Thiobacillus. Isolate LM3 is described as the type strain of the new species Thiobacillus prosperus.
\end{abstract}

Key words: Thiobacillus - Leaching - Chemolithotrophic - Acidophilic - Marine

The ability to grow chemolithoautotrophically on sulfidic ores is up to now restricted to Thiobacillus ferrooxidans (Colmer and Hinkle 1947), Leptospirillum ferrooxidans (Balashova et al. 1974) and to the archaebacterium Acidianus brierleyi (Brierley and Murr 1973; Segerer et al. 1986). During growth sulfuric acid is formed and heavy metals are solubilized (,leaching").

The members of the genus Thiobacillus are Gram negative rod-shaped eubacteria, which are classified in three main groups based on the kind of energy metabolism (obligately or facultatively chemolithotrophic) and the possession of ubiquinone 10 or 8 . They are further divided by the $G+C$ content and the physiological properties of the different species (Katayama-Fujimura et al. 1982). All of them gain their energy by the oxidation of reduced sulfur compounds to sulfate (Vishniac 1974). T. ferrooxidans is able to grow also on water-insoluble metal sulfides and sulfidic ores like pyrite, chalcopyrite or sphalerite, performing the bacterial leaching process (Lundgren et al. 1986). T. ferrooxidans is further characterized by its ability to oxidize ferrous to ferric iron (Colmer and Hinkle 1947), enhancing the leaching process due to the strong oxidizing capacity of $\mathrm{Fe}^{3+}$ ("indirect leaching"). It was isolated from acid mine waters and from soils containing pyrite and marcasite (Vishniac 1974), but

Offprint requests to: $\mathrm{K}$. O. Stetter was not found in marine environments (Tuttle and Jannasch 1972). This corresponds to the inability of $T$. ferrooxidans to grow at salt concentrations above 1\% (Razzell and Trussell 1963; Lazaroff 1963).

Here we describe a group of halotolerant marine metalmobilizing rod-shaped thiobacilli which are different from T. ferrooxidans.

\section{Materials and methods}

\section{Strains}

The type strains of Thiobacillus ferrooxidans (ATCC 23270), Thiobacillus thiooxidans (ATCC 19377) and Thiobacillus perometabolis (ATCC 23370) were obtained from the American Type Culture Collection, Thiobacillus novellus (DSM 506), Thiobacillus neapolitanus (DSM 581) and Thiobacillus thioparus (DSM 505) from the Deutsche Sammlung von Mikroorganismen, Braunschweig, FRG.

\section{Culture conditions}

$T$. ferrooxidans and $T$. thiooxidans were grown in "9K"medium (Silverman and Lundgren 1959). T. novellus and $T$. perometabolis were cultivated in medium A (KatayamaFujimura and Kuraishi 1980). For the cultivation of $T$. thioparus medium 2 (Starkey 1934) and for T. neapolitanus the T. thioparus-medium (Vishniac and Santer 1957) was used.

The new isolates were usually cultivated in the mineral salt medium "M1" (Huber et al. 1986), adjusted to $\mathrm{pH} 2.5$ with sulfuric acid and supplemented with ore mixture "G1" ( $1 \mathrm{~g} / 30 \mathrm{ml}$ medium). "G1" consisted of equal parts of pyrite (Grube Bayerland, Oberpfalz), chalcopyrite (Bad Grund, Harz), sphalerite (Grube Lüderich, Nordrhein-Westfalen) and pitch blend (Grube Höhenstein, Oberpfalz). The particle size was below $1 \mathrm{~mm}$. The mineral composition of these ores was:

Pyrite: $90 \%$ pyrite; traces of chalcopyrite, rutile and pyrrhotin;

Chalcopyrite: $85 \%$ chalcopyrite; $10 \%$ pyrite; traces of galena;

Sphalerite: $90 \%$ sphalerite; $5 \%$ galena; traces of pyrite and chalcopyrite;

Pitch blend: $5 \%$ pyrite; $1 \%$ pitch blend; traces of anastase, zircon and chalcopyrite;

In all ores the matrix consisted of silicates. Chemical composition of the ore mixture "G1" $(1 \mathrm{~g}$ dissolved in $30 \mathrm{ml}$ 
aqua regia): As $45 \mathrm{ppm}$; $\mathrm{Cd} 14 \mathrm{ppm}$; Co $5 \mathrm{ppm}$; $\mathrm{Cu}$ $2000 \mathrm{ppm}$; Fe $6000 \mathrm{ppm}$; Ge $65 \mathrm{ppm}$; Hg $8 \mathrm{ppm}$; Mn 28 ppm; Pb 250 ppm; Th 5 ppm; Ti 3 ppm; U 90 ppm; Y 2 ppm; Yb 4 ppm; Zn 4000 ppm; Zr 4 ppm.

Cerium, chromium, gold, molybdenum, nickel, silver, tin and vanadium were not found in detectable amounts.

Ferrous sulfate $(4 \%, w / v)$, sodium thiosulfate $(0.5 \%)$, potassium tetrathionate $(0.5 \%)$, sugars (e.g. glucose, galactose, saccharose; each $0.1 \%)$, yeast extract $(0.05 \%)$, peptone $(0.05 \%)$, elemental sulfur $(0.05 \%)$, synthetic sulfides $\left(\mathrm{Ag}_{2} \mathrm{~S}, \mathrm{CdS},{ }^{\mathrm{CuS}}, \mathrm{FeS}, \mathrm{MoS}_{2}, \mathrm{Sb}_{2} \mathrm{~S}_{3}, \mathrm{SnS}, \mathrm{ZnS}\right.$; each $1.7 \%$ ) and natural ores (arsenopyrite (FeAsS), Reichenstein, Poland; galena (PbS), Clausthal, FRG; each $3.3 \%$ ) were tested as further possible substrates.

The salt tolerance of the organisms was determined in the presence of the ore mixture " $\mathrm{G1}$ " by adding sterile $\mathrm{NaCl}$ up to the final concentrations.

All organisms were grown aerobically under shaking $(100 \mathrm{rev} / \mathrm{min})$ in $100 \mathrm{ml}$ Erlenmeyer flasks containing $30 \mathrm{ml}$ medium. Large scale cultures were grown in 851 enamelprotected fermentors (HTE, Bioengineering, Wald, Switzerland) under gassing with air $(2 \mathrm{l} / \mathrm{min})$ and stirring $(150 \mathrm{rev} / \mathrm{min})$. In these cultures the cell yield of the new isolates was about $1 \mathrm{~g}$ (wet weight) $/ 100 \mathrm{l}$ medium.

\section{Light microscopy}

The cultures were routinely observed with a Zeiss Standard 16 phase contrast microscope using an oil immersion objective 100/1.3. For the visualization of cells attached to ores a modified DAPI procedure (Huber et al. 1985) including the fluorescence equipment IV FL with an excitation filter BP 365 and a selection filter LP 420 was used.

\section{Electron microscopy}

Cultures, fixed with glutaraldehyde $(2 \%)$, were dropped onto collodium coated grids and platinum shadowed at an angel of $7^{\circ}$. Thin sections were prepared according to Huber et al. (1982). Electron micrographs were taken with a Jeol JEM $100 \mathrm{C}$ electron microscope.

\section{Determination of growth}

Bacterial growth was determined by direct cell counting in a "Thoma"-counting chamber, depth $0.02 \mathrm{~mm}$.

\section{Tolerance against heavy metals}

Stock solutions or salts of different heavy metal ions were added after separate sterilization to the culture media in the following final concentrations:

salt

$\mathrm{AgNO}_{3}$

$\mathrm{NaAsO}_{2}$

$\left(\mathrm{CH}_{3} \mathrm{COO}\right)_{2} \mathrm{Cd} \times 2 \mathrm{H}_{2} \mathrm{O}$

$\mathrm{CoSO}_{4} \times 7 \mathrm{H}_{2} \mathrm{O}$

$\mathrm{CuSO}_{4} \times 5 \mathrm{H}_{2} \mathrm{O}$

$\mathrm{HgSO}_{4}$

$\mathrm{Na}_{2} \mathrm{MoO}_{4} \times 2 \mathrm{H}_{2} \mathrm{O}$

$\mathrm{NiSO}_{4} \times 6 \mathrm{H}_{2} \mathrm{O}$

$\mathrm{SbCl}_{3}$

$\left(\mathrm{CH}_{3} \mathrm{COO}\right)_{2} \mathrm{UO}_{2} \times 2 \mathrm{H}_{2} \mathrm{O}$

$\mathrm{ZnSO}_{4} \times 7 \mathrm{H}_{2} \mathrm{O}$ final metal ion concentrations (mM) $0.0009 ; 0.009 ; 0.09 ; 0.9$;

$0.013 ; 0.13 ; 1.3 ; 13$;

$0.009 ; 0.09 ; 0.9 ; 9$;

$1.7 ; 17 ; 85 ; 170 ; 850$;

$1.6 ; 16 ; 79 ; 160 ; 790$;

$0.0005 ; 0.005 ; 0.05 ; 0.5$;

$0.01 ; 0.1 ; 1 ; 10$;

$1.7 ; 17 ; 170 ; 850 ; 1700$;

$0.008 ; 0.08 ; 0.8 ; 8$;

$0.004 ; 0.04 ; 0.4 ; 4$

$1.5 ; 15 ; 150 ; 750 ; 1500 ; 3000$
Quantitative determination of sulfate

Sulfate was determined gravimetrically after precipitation by $\mathrm{BaCl}_{2}$ according to Williams (1979).

\section{Test for diaminopimelic acid}

Diaminopimelic acid was determined chromatographically (Rhuland et al. 1955).

\section{Isolation of DNA}

DNA of cells ( $0.5 \mathrm{~g}$ wet weight) was isolated according to Wildgruber et al. (1982).

\section{DNA base composition}

The $\mathrm{G}+\mathrm{C}$ content of the DNAs was determined by the $\mathrm{T}_{\mathrm{M}^{-}}$ method in $0.1 \times$ SSC (Marmur and Doty 1962) and by direct analysis of the nucleotides after digestion with nuclease P1 (Zillig et al. 1980) by HPLC chromatography.

\section{DNA-DNA homology}

DNA-DNA hybridization was performed (König 1984) after radioactive in-vitro labelling of the DNA by nick translation (Kelly et al. 1970) using the filter technique (Gillespie and Gillespie 1971; Birnstiel et al. 1972).

\section{Metal analysis}

Concentrations of the elements, detected in the ore mixture "G1", were determined quantitatively in the aqua regia solutions or in the supernatant of the centrifugated cultures with an "ICP" (Inductively Coupled Plasma) instrument (Lab Test). The results of the bacterial leaching were the average from three parallel experiments. The variation of the extraction values was below $15 \%$.

\section{Results}

\section{Enrichment and isolation of the new organisms}

Samples $(20 \mathrm{ml})$ of sediments and waters were taken at different sites at the marine hydrothermal area at Porto di Levante, Vulcano, Italy (Table 1). In the laboratory, enrichment cultures were set up after the addition of about $1 \mathrm{~g}$ of samples into the sterile ore mixture " $G$ "-containing mineral culture medium. After 2 weeks incubation at $37^{\circ} \mathrm{C}$ long thin rods became visible in the enrichment cultures from the samples L7, LM1, LM3, MSB9a, MSB11, MSB12, VC15 and VM17. The positive enrichments were purified by serial dilutions carried out at least three times in the ore-containing medium. The isolates were designated the same as the samples. Enrichment attempts from marine hydrothermal systems at Ischia, Naples, Iceland and Guaymas did not yield similar organisms (not shown).

\section{Morphology}

In the phase contrast microscope cells of the new isolates appeared as tiny rods, either motile in suspension or attached to the ore surface (about $50 \%$ ). The organisms were up to $4 \mu \mathrm{m}$ long and $0.2-0.4 \mu \mathrm{m}$ wide (Fig. 1). The cells possessed 
Table 1

Samples yielding positive enrichment cultures from the beach at Porto di Levante, Vulcano, Italy

Designation Sample taken from
of sample

of sample

Original

temperature

Depth

$\left({ }^{\circ} \mathrm{C}\right)$
L7

LM1

LM3

MSB9a

MSB11

MSB12

VC15

The $\mathrm{pH}$ of all samples was around 6.5

\begin{tabular}{|c|c|c|}
\hline Turbid water and small grey stones from a small spring & 37 & 0.3 \\
\hline Light sand from a large spring & 33 & 1 \\
\hline Coarse-grained sediment besides a large spring & 35 & 1 \\
\hline Black sandy sediment from a small well & 92 & 1 \\
\hline Black sandy sediment & 85 & 1 \\
\hline Sulfur-covered lava stones in a spring & 90 & 1 \\
\hline Grey sandy sediment & 30 & 0.1 \\
\hline Strongly gassed grey and sandy sediment & 37 & 0.5 \\
\hline
\end{tabular}

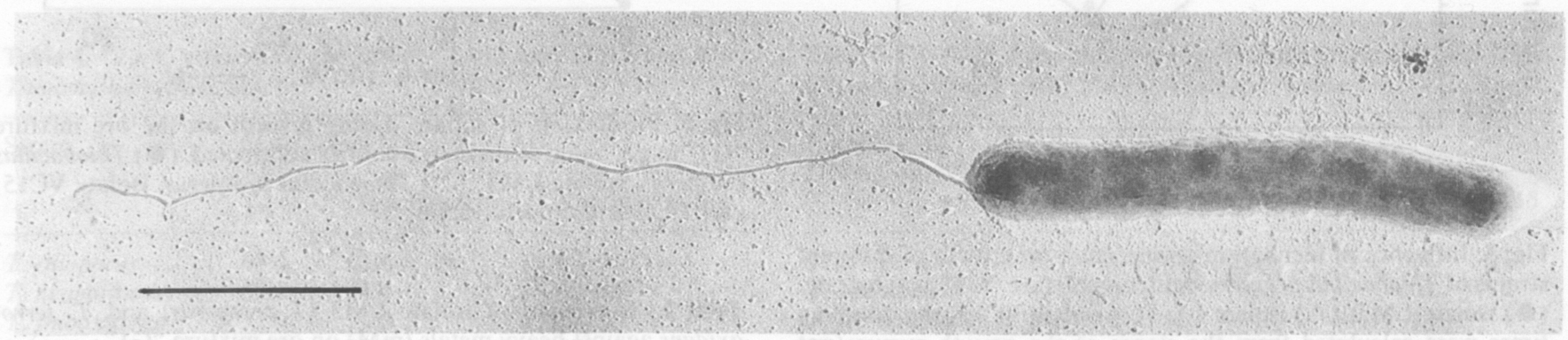

Fig. 1. Electron micrograph of Thiobacillus prosperus (isolate LM3) platinum shadowed, showing a monopolar monotrichous flagellation. Bar $1 \mu \mathrm{m}$

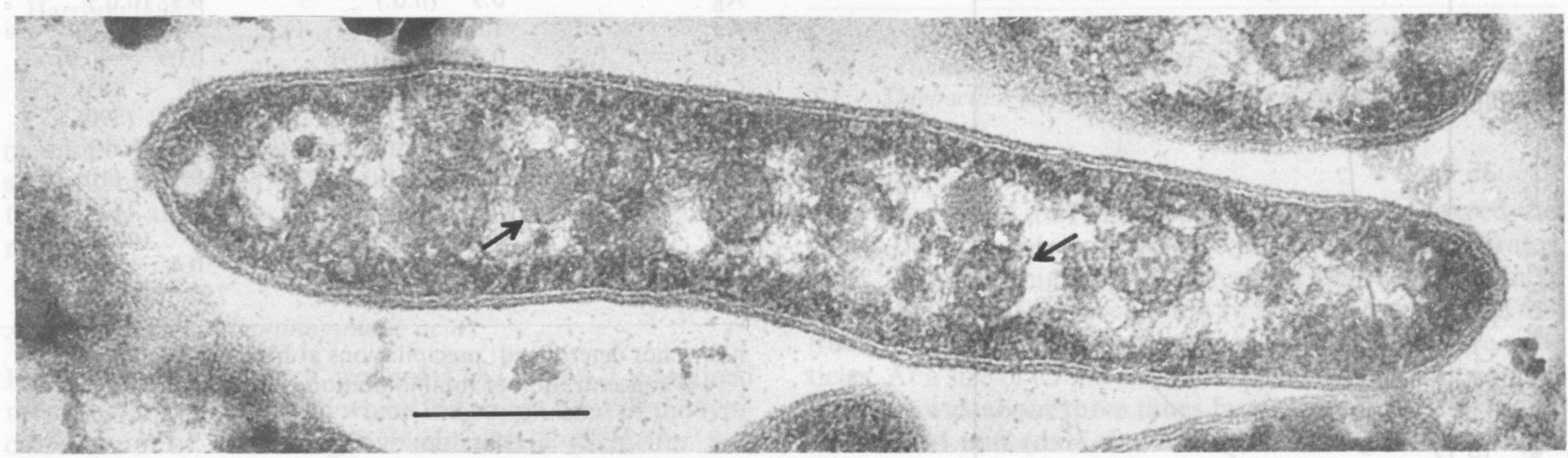

Fig. 2. Thin section of Thiobacillus prosperus (isolate LM3), contrasted with lead citrate and uranyl acetate. Bar $0.2 \mu \mathrm{m}$

one polar flagellum which was about $4 \mu \mathrm{m}$ long (Fig. 1). They contained frequently granum-like bodies about $0.1-$ $0.2 \mu \mathrm{m}$ in width (Figs. 1, 2, arrows). They stained Gramnegative.

\section{Storage}

Cultures grown on ores and stored at room temperature served as inocula for at least 18 months. When stored in the cold room $\left(4^{\circ} \mathrm{C}\right)$, the cells lost their viability within 2 weeks. Freezing at $-20^{\circ} \mathrm{C}$ or $-140^{\circ} \mathrm{C}$ (liquid nitrogen; gasphase) in the presence or absence of glycerol $(20 \% \mathrm{w} / \mathrm{v})$ or dimethylsulfoxid $(5 \% \mathrm{w} / \mathrm{v})$ led to complete inactivation of the cultures.

\section{Growth temperatures}

The isolates L7, LM3 and VC15 grew at temperatures above $20^{\circ} \mathrm{C}$ and below $45^{\circ} \mathrm{C}$ (strain VC15 below $41^{\circ} \mathrm{C}$ ). For the isolates L7 and VC15 fastest growth (Fig. 3) was obtained at $37^{\circ} \mathrm{C}$ (doubling time 8 , respectively $6 \mathrm{~h}$ ). Isolate LM3 grew optimally at $33^{\circ} \mathrm{C}$ (doubling time $6 \mathrm{~h}$ ).

\section{pH of growth}

All isolates grew between $\mathrm{pH} 1$ and 4.5 with an optimum around 2. During growth on the ore mixture "G1" the $\mathrm{pH}$ dropped due to the production of sulfuric acid.

Although cells did not grow in media adjusted to $\mathrm{pH} 6.5$, they survived and could successfully be transferred for at least 2 weeks into fresh media with $\mathrm{pH} 2.5$ (storage temperature $37^{\circ} \mathrm{C}$ ).

\section{Salt tolerance}

Isolates L7, LM1, LM3, MSB9a, MSB11, MSB12 and VC15 grew at $\mathrm{NaCl}$ concentrations of up to $3.5 \%$ (Fig. 4; not shown), added to the basal medium. Strain VM17 grew 


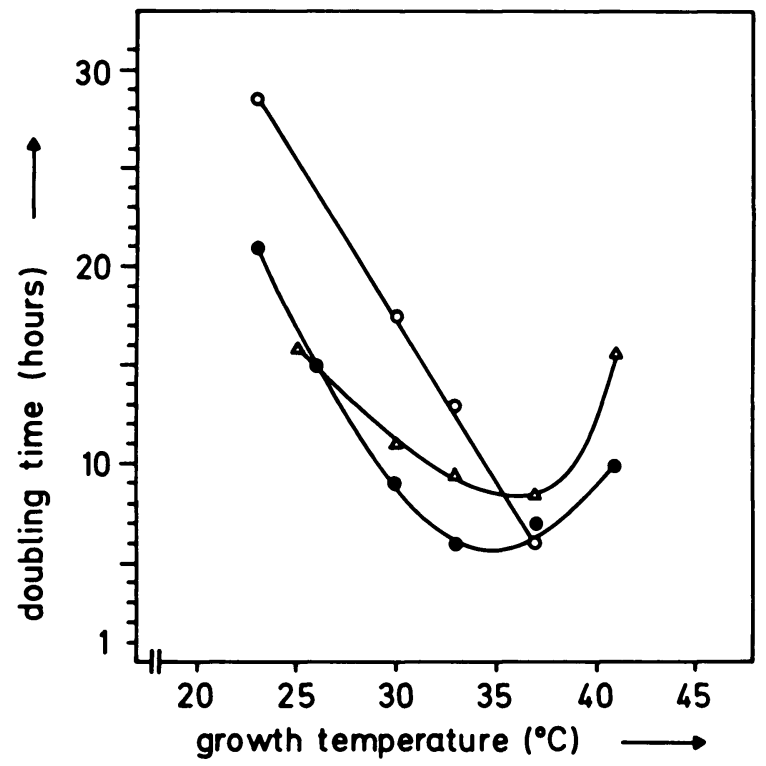

Fig. 3. Influence of incubation temperature on growth of different strains of Thiobacillus prosperus with ore mixture "G1" as substrate. $(O)$ isolate LM3; $(\triangle)$ isolate $\mathrm{L} 7 ;(O)$ isolate VC15; the doubling times were calculated from the slopes of the growth curves (not shown)

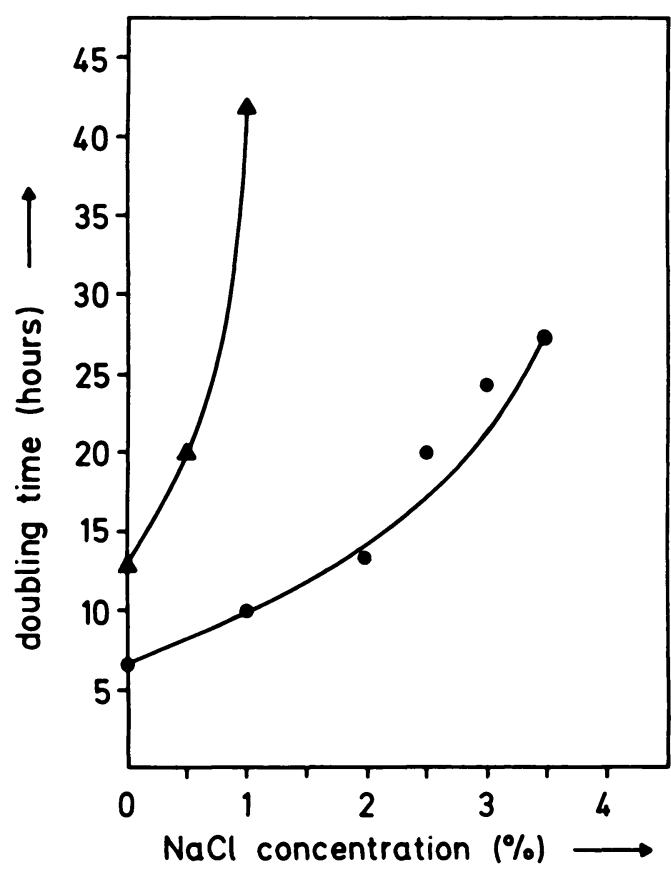

Fig. 4. Effect of $\mathrm{NaCl}$ concentrations added to the basal medium with "G1" as substrate. (O) Thiobacillus prosperus, isolate LM3; (A) Thiobacillus ferrooxidans; the doubling times were calculated from the growth curves (not shown)

even up to concentrations of $6 \% \mathrm{NaCl}$ (not shown). Fastest growth (Fig. 4) and highest final cell concentrations were obtained without additional salt. As expected T. ferrooxidans did not grow at $\mathrm{NaCl}$ concentrations higher than $1.0 \%$ (Fig. 4).

All new isolates were able to grow in the presence of seawater.

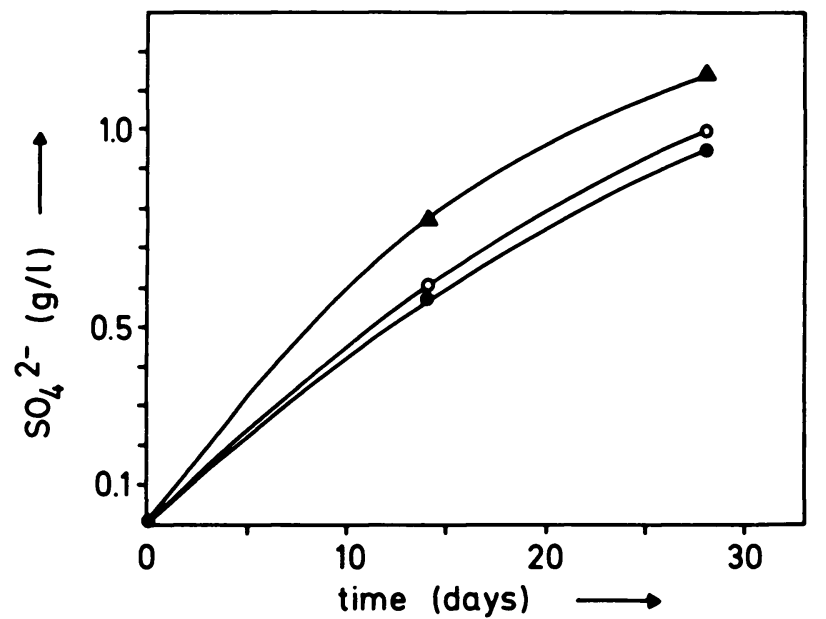

Fig. 5. Production of sulfate during growth on the ore mixture "G1" in $\mathrm{g} / \mathrm{l}$, value of the sterile control subtracted. (O) Thiobacillus prosperus, isolate LM3; (O) Thiohacillus prosperus, isolate VC15; (A) Thiobacillus ferrooxidans

Table 2. Tolerances of isolate LM3 ( $T$. prosperus) and $T$. ferrooxidans against heavy metals $(\mathrm{mM})$ on ore mixture "G1"

\begin{tabular}{lcccc}
\hline Element & \multicolumn{2}{c}{ Isolate LM3 } & \multicolumn{2}{c}{ T. ferrooxidans } \\
\hline $\mathrm{Ag}$ & 0.9 & (n.d.) & 0.9 & (n.d.) \\
$\mathrm{As}$ & 1.3 & $(13)$ & 1.3 & $(13)$ \\
$\mathrm{Cd}$ & 0.009 & $(0.09)$ & 0.09 & $(0.9)$ \\
$\mathrm{Co}$ & 170 & $(850)$ & 17 & $(85)$ \\
$\mathrm{Cu}$ & 16 & $(79)$ & 160 & $(790)$ \\
$\mathrm{Hg}$ & 0.05 & $(0.5)$ & 0.5 & $($ n.d.) \\
$\mathrm{Mo}$ & 1 & $(10)$ & 0.1 & $(10)$ \\
$\mathrm{Ni}$ & 850 & $(1700)$ & 170 & $(850)$ \\
$\mathrm{Sb}$ & 8 & $($ n.d.) & 8 & $($ n.d.) \\
$\mathrm{U}$ & 0.04 & $(0.4)$ & 0.4 & $(4)$ \\
$\mathrm{Zn}$ & 1500 & $(3060)$ & 750 & $(1530)$ \\
\hline
\end{tabular}

n.d. = not determined precipitations at higher concentrations ()$=$ concentration of total inhibition

\section{Metabolism}

The new isolates grew aerobically on single sulfidic ores like pyrite, sphalerite, chalcopyrite, arsenopyrite and galena as energy source. During growth on the ore mixture "G1" the new isolates and $T$. ferrooxidans formed about $10 \mathrm{mM}$ sulfate within 28 days (Fig. 5; final cell concentration about $2 \times 10^{8} / \mathrm{ml}$ ). Growth of all isolates was neither stimulated nor inhibited by the addition of yeast extract $(0.02 \%)$. The sulfidic ores could be substituted by $\mathrm{H}_{2} \mathrm{~S}$ as substrate. Thiosulfate, tetrathionate and the synthetic sulfides $\mathrm{Ag}_{2} \mathrm{~S}$, $\mathrm{CuS}, \mathrm{FeS}, \mathrm{MoS}_{2}, \mathrm{Sb}_{2} \mathrm{~S}_{3}, \mathrm{SnS}$ and $\mathrm{ZnS}$ did usually not serve as substrate. As an exception, isolate VC15 was able to grow by oxidation of synthetic FeS. All isolates were unable to grow on organic substrates like yeast extract, saccharose and glucose.

Elemental sulfur and ferrous sulfate were used as substrates by the strains LM1, MSB9a and VM17. Isolates L7, LM3, VC15, MSB11 and MSB12 appeared to be unable to use one or both of these substrates when they were precultured on sulfidic ores. However, they could be adapted to these substrates after about 5 transfers in "G1"-containing 
Table 3. Metal extraction by the new isolates and by Thiobacillus ferrooxidans from the ore mixture "G1" in 28 days (g/l)

\begin{tabular}{|c|c|c|c|c|c|c|c|c|c|c|}
\hline \multirow[t]{2}{*}{ Element } & \multicolumn{8}{|c|}{ Strain } & \multirow{2}{*}{$\begin{array}{l}\text { Sterile } \\
\text { control }^{\text {a }}\end{array}$} & \multirow{2}{*}{$\begin{array}{l}\text { Total } \\
\text { amount }^{b}\end{array}$} \\
\hline & L7 & LM1 & LM3 & MSB9 & MSB11 & MSB12 & VC15 & T.f. & & \\
\hline $\mathrm{Cu}$ & 0.15 & 0.09 & 0.16 & 0.13 & 0.12 & 0.13 & 0.12 & 0.16 & 0.04 & 2.00 \\
\hline $\mathrm{Fe}$ & 0.13 & 0.25 & 0.19 & 0.22 & 0.23 & 0.25 & 0.18 & 0.24 & 0.22 & 6.00 \\
\hline $\mathrm{U}$ & 0.08 & 0.05 & 0.09 & 0.05 & 0.05 & 0.05 & 0.06 & 0.06 & 0.01 & 0.09 \\
\hline $\mathrm{Zn}$ & 1.43 & 1.45 & 1.65 & 1.41 & 1.24 & 1.27 & 1.55 & 1.85 & 0.50 & 4.00 \\
\hline
\end{tabular}

T.f. = Thiobacillus ferrooxidans

a Chemical extraction by sulfuric acid from the medium

b Determined by chemical extraction with concentrated aqua regia

Table 4. G + C content of the isolates LM3 and VC15 and some Thiobacillus type strains

\begin{tabular}{llll}
\hline Strain & \multicolumn{3}{l}{$\mathrm{G}+\mathrm{C}(\mathrm{mol} \%)$} \\
\cline { 2 - 4 } & $\mathrm{T}_{\mathrm{M}}$ & Direct analysis & Reference value \\
\hline T. thioparus & 64.4 & 62.4 & $62-66^{\mathrm{a}}$ \\
$T$. neapolitanus & 55.1 & 54.4 & $55-57^{\mathrm{a}}$ \\
$T$. thiooxidans & 52.0 & 54.4 & $52^{\mathrm{b}}$ \\
$T$. ferrooxidans & 59.2 & 58.7 & $58^{\mathrm{b}}$ \\
LM3 & 64.4 & 64.4 & \\
VC15 & 63.1 & 62.1 & \\
\hline
\end{tabular}

a Harrison (1982)

b Kuenen and Tuovinen (1984)

medium which were supplemented with $\mathrm{Fe}^{2+}$ or elemental sulfur. On $\mathrm{Fe}^{2+}$ and elemental sulfur the final cell concentrations of all isolates were rather poor (about $4 \times 10^{7}$ cells/ $\mathrm{ml})$.

\section{Analysis of meso-diaminopimelic acid}

Hydrolysates of cells of isolates LM3 and L7 contained meso-diaminopimelic acid which is a component of the typical murein of Gram-negative eubacteria (Schleifer and Kandler 1972).

\section{Resistance against heavy metals}

The resistances of isolate LM3 and of Thiobacillus ferrooxidans against heavy metals were examined in the presence of various concentrations of different heavy metal ions (Table 2). In comparison with $T$. ferrooxidans strain LM3 was about one order of magnitude more sensitive against ions of cadmium, mercury and uranium, while it was more resistant against cobalt, molybdenum, nickel and zinc. Isolate LM3 was even able to grow in the presence of $850 \mathrm{mM}$ of nickel and of $1500 \mathrm{mM}$ of zinc ions.

\section{Ore leaching capacity}

On the ore mixture "G1" the new isolates and Thiobacillus ferrooxidans showed very similar patterns and final concentrations of solubilized metal ions (Table 3). The new strains extracted up to $100 \%$ uranium, $40 \%$ zinc and up to $8 \%$ copper within 28 days. Solubilized iron was precipitated as jarosite (D. Rose, pers. communication). Therefore, the
Table 5. DNA-DNA homologies (\%) between the new isolates LM3, L7 and VC15 and some Thiobacillus type strains

\begin{tabular}{lrrrrrrr}
\hline Filter-bound & \multicolumn{7}{l}{32 P-labelled DNA from } \\
\cline { 2 - 7 } DNA from & T.tp. & T.n. & T.f. & T.t. & LM3 & L7 & VC15 \\
\hline T. thioparus & 100 & 18 & n.d. & n.d. & 15 & n.d. & 10 \\
$T$. neapolitanus & 9 & 100 & 1 & n.d. & 19 & n.d. & 1 \\
$T$. ferrooxidans & 3 & 8 & 100 & 12 & 14 & 13 & 6 \\
$T$. thiooxidans & n.d. & n.d. & 3 & 100 & 15 & n.d. & 1 \\
LM3 & 6 & 11 & 4 & 12 & 100 & 98 & 15 \\
L7 & n.d. & n.d. & 9 & 12 & 91 & 100 & n.d. \\
VC15 & 12 & n.d. & 7 & n.d. & 36 & n.d. & 100 \\
\hline
\end{tabular}

n.d. = not determined

T.tp. = Thiobacillus thioparus; T.n.= Thiobacillus neapolitanus; T.f. = Thiobacillus ferrooxidans; T.t. = Thiobacillus thiooxidans

concentration of iron in the supernatant did not exceed the values of the sterile control. The maximal extraction rates of 5,120 and $7 \mathrm{mg} / \mathrm{l}$ per day, respectively, were obtained about 3 weeks after inoculation (data not shown). The extraction rates depended strongly on the size of the ore particles. At a size of $63 \mu \mathrm{m}$ and below, the extraction of copper and zinc was about three times faster than that of particles of below $1 \mathrm{~mm}$ (data not shown). The higher extraction velocity may be due to the larger surface available to the organisms. In media containing $3.5 \% \mathrm{NaCl}$ in addition no significant differences in the leaching capacity were detected for all isolates (data not shown).

\section{Content of quinones}

The new isolates contained ubiquinone $8\left(\mathrm{CoQ}_{8}\right)$ as their main quinone $(96.5 \%)$. No ubiquinone 10 was detected (D. Collins, pers. communication).

\section{DNA composition}

The $\mathrm{G}+\mathrm{C}$ content of the DNA was determined for the isolates LM3 and VC15 and for some Thiobacillus reference strains (Table 4). The isolates LM3 and VC15 exhibited $\mathrm{G}+\mathrm{C}$ contents of around 64 and $63 \mathrm{~mol} \%$ respectively.

\section{DNA-DNA hybridization}

DNA-DNA hybridization between the isolates L7, LM3, VC15 and Thiobacillus reference strains was carried out. 
Isolates L7 and LM3 were chosen since they were the first strains obtained in pure culture. Strain VC15 was different from the other isolates by its ability to grow on $\mathrm{FeS}$. Isolates LM3 and L7 showed more than $90 \%$ homology between each other (Table 5). There was only a low DNA homology between isolates VC15 and LM3 (25\% average; Table 5). No significant homology could be detected between isolates L7, LM3, VC15 and the Thiobacillus reference strains.

\section{Discussion}

The new isolates are mesophilic rod-shaped Gram-negative eubacteria able to oxidize sulfur compounds and even sulfidic ores to sulfate and are therefore members of the genus Thiobacillus (Vishniac 1974). Due to their obligately chemolithotrophic acidophilic mode of life and their possession of ubiquinone Q-8 they can be attached to the chemotaxonomic group III-3 within the genus Thiobacillus (Katayama-Fujimura et al. 1982). Thiobacillus ferrooxidans belongs to the same group. The eight new isolates can be easily distinguished from $T$. ferrooxidans by their tiny slender shape, their growth in the presence of at least $3.5 \% \mathrm{NaCl}$ and their very poor growth on elemental sulfur and on ferrous iron. The isolates LM3, L7 and VC15 had been inspected more closely. They exhibit a $G+C$ content of their DNA $5 \%$ higher than $T$. ferrooxidans and show no significant DNA hybridization with $T$. ferrooxidans and other Thiobacillus group III members. Between each other, isolates LM3 and L7 exhibit over $90 \%$ DNA hybridization and are therefore strains of the same new species. Isolate VC15 shows only a rather low DNA hybridization with isolates LM3 and L7 and is therefore different. Up to now the only taxonomic feature further distinguishing isolate VC15 from the other isolates is its ability to grow on synthetic ferrous sulfide. Therefore, the description of a separate taxon seems to us not to be justified at the moment. On the basis of the morphological, physiological and molecular differences mentioned above, which separate the new isolates clearly from the known members of the genus Thiobacillus, we describe one new species which we name Thiobacillus prosperus sp. nov. due to its ability to extract pretious metal ions from ores. The type strain is Thiobacillus prosperus LM3 (DSM 5130).

The new species Thiobacillus prosperus represents the first halotolerant metal-mobilizing bacterium isolated. Similar to $T$. ferrooxidans it shows vigorous extraction of metal ions from sulfidic ores. $T$. prosperus shows an extremely high resistance against cobalt, nickel and zinc ions. Due to its high tolerance of salt (even $6 \%$ in the case of isolate VM17), $T$. prosperus may be suitable for industrial leaching in saltcontaining environments where $T$. ferrooxidans is unable to grow. Within its natural environment at the marine hydrothermal system at Vulcano, $T$. prosperus may grow mainly by oxidation of pyrite deposits, which are currently formed (Wauschkuhn and Gröpper 1975). Although T. prosperus cannot grow at the high pH of regular sea water, there may be most probably acidic microenvironments formed by $\mathrm{SO}_{2}$ containing submarine fumaroles suitable for it to grow.

\section{Description of a new species}

Thiobacillus prosperus Huber and Stetter, sp. nov. pros'pe.rus L. masc. adj. prosperus prosperous, referring to its ability to gain precious metals by ore "leaching".
Cells are Gram-negative rods, about 3 to $4 \mu \mathrm{m}$ long and $0.3 \mu \mathrm{m}$ in width and are motile by one polar flagellum. Optimal growth around $37^{\circ} \mathrm{C}$ and up to $41^{\circ} \mathrm{C}$. Growth from $0 \%$ to $3.5 \% \mathrm{NaCl}$, and between $\mathrm{pH} 1.0$ and 4.5 . Strictly chemolithoautotrophic and aerobic. Growth on sulfidic ores like pyrite, sphalerite, chalcopyrite, arsenopyrite, galena and on $\mathrm{H}_{2} \mathrm{~S}$. Poor growth on elemental sulfur and ferrous iron. Produces sulfuric acid from reduced sulfur compounds. Sensitive to ampicillin and vancomycin, possess $m-D A P$ and ubiquinone Q-8. G + C content of the DNA $64 \mathrm{~mol} \%$. Insignificant DNA hybridization to $T$. ferrooxidans, $T$. thiooxidans, T. neapolitanus and T. thioparus. Lives in marine sediments in hydrothermal areas.

Type strain is Thiobacillus prosperus, LM3, DSM 5130, Braunschweig, FRG.

Acknowledgement. The excellent technical assistance of Hannelore Nowarra and Silvia Sur is highly appreciated. We wish to thank Dr. Ortwin Lossen and Gisela Emmert for ICP analyses and Dr. D. Collins for kindly providing unpublished results. This work was supported by grants of the Bundesministerium für Forschung und Technologie (BMFT, Projektleitung Rohstofforschung, Förderungskennzeichen $03 \mathrm{C} 1420$ and $03 \mathrm{R} 085 \mathrm{~A}$ 2) and by the Fonds der Chemischen Industrie.

\section{References}

Balashova VV, Vedenina IYa, Markosyan GE, Zavarzin GA (1974) The autotrophic growth of Leptospirillum ferrooxidans. Translated from: Mikrobiologiya 43:581-585

Birnstiel ML, Sells BH, Purdom IF (1972) Kinetic complexity of RNA molecules. J Mol Biol 63:21 - 39

Brierley CL, Murr LE (1973) Leaching: use of a thermophilic and chemoautotrophic microbe. Science 179:488-490

Colmer AR, Hinkle ME (1947) The role of microorganisms in acid mine drainage: a preliminary report. Science 106:253-256

Gillespie S, Gillespie GD (1971) Ribonucleic acid - deoxyribonucleic acid hybridization in aqueous solutions and in solutions containing formamide. Biochem J 125:481-487

Harrison AP Jr (1982) Genomic and physiological diversity amongst strains of Thiobacillus ferrooxidans and genomic comparison with Thiobacillus thiooxidans. Arch Microbiol 131:68-76

Huber H, Thomm M, König H, Thies G, Stetter KO (1982) Methanococcus thermolithotrophicus, a novel thermophilic lithotrophic methanogen. Arch Microbiol 132:47-50

Huber H, Huber G, Stetter KO (1985) A modified DAPI fluorescence staining procedure suitable for the visualization of lithotrophic bacteria. Syst Appl Microbiol 6:105-106

Huber G, Huber H, Stetter KO (1986) Isolation and characterization of new metal-mobilizing bacteria. Biotech Bioeng Symp $16: 239-251$

Katayama-Fujimura Y, Kuraishi H (1980) Characterization of Thiobacillus novellus and its thiosulfate oxidation. J Gen Microbiol 26:257-367

Katayama-Fujimura Y, Tsuzaki N, Kuraishi H (1982) Ubiquinone, fatty acid and DNA base composition determination as a guide to the taxonomy of the genus Thiobacillus. J Gen Microbiol 128:1599-1611

Kelly RB, Cozzarelli NR, Deutscher MP, Lehmann JR, Kornberg A (1970) Enzymatic synthesis of deoxynucleic acid by polymerase at single strand break. J Biol Chem 245:39-45

König H (1984) Isolation and characterization of Methanobacterium uliginosum sp. nov. from a marshy soil. Can J Microbiol 30:1477-1481

Kuenen JG, Tuovinen OH (1981) The genera Thiobacillus and Thiomicrospira. In: Starr MP, Stolp H, Trüper HG, Balows A, Schlegel HG (eds) The prokaryotes. Springer, Berlin Heidelberg New York, pp 1023-1036 
Lazaroff $N$ (1963) Sulfate requirement of iron oxidation by Thiobacillus ferrooxidans. J Bacteriol 85:78-83

Lundgren DG, Valkova-Valachanova M, Read R (1986) Chemical reactions important in bioleaching and bioaccumulation. Biotech Bioeng Symp 16:7-22

Marmur J, Doty P (1962) Determination of the base composition of deoxyribonucleic acid from its thermal denaturation temperature. J Mol Biol 5:109-118

Razzell WE, Trussel PC (1963) Isolation and properties of an ironoxidizing Thiobacillus. J Bacteriol 85:595-603

Rhuland LE, Work E, Denman RF, Hoare DS (1955) The behavior of the isomers of $\alpha, \varepsilon$ diamino-pimelic acid on paper chromatographs. J Am Chem Soc 77:4844-4846

Schleifer KH, Kandler O (1972) Peptidoglycan types of bacterial cell walls and their taxonomic implications. Bacteriol Rev 36:407477

Segerer A, Neuner A, Kristjansson JK, Stetter KO (1986) Acidianus infernus gen. nov., sp. nov., and Acidianus brierleyi comb. nov.: facultatively aerobic, extremely acidophilic thermophilic sulfurmetabolizing archaebacteria. Int J Syst Bacteriol 36:559-564

Silverman MP, Lundgren DG (1959) Studies on the chemoautotrophic iron bacterium Ferrobacillus ferrooxidans. I. An improved medium and a harvesting procedure for securing high cell yields. J Bacteriol 77:642-647
Starkey RL (1934) Cultivation of organisms concerned in the oxidation of thiosulfate. J Bacteriol 28:365-386

Tuttle JH, Jannasch HW (1972) Occurrence and types of Thiobacillus-like bacteria in the sea. Limnol Ocean 17:532-543

Vishniac WV (1974) The genus Thiobacillus. In: Buchanan RE, Gibbons NE (eds) Bergey's manual of determinative bacteriology, 8th edn. Williams and Wilkins, Baltimore, pp 456-461

Vishniac WV, Santer M (1957) The Thiobacilli. Bacteriol Reviews $21: 195-213$

Wauschkuhn SA, Gröpper H (1975) Rezente Sulfidbildung auf und bei Vulcano, Äolische Inseln, Italien. Neues Jahrb Minerol Abh 126:87-111

Wildgruber G, Thomm M, König H, Ober K, Ricchiuto T, Stetter KO (1982) Methanoplanus limicola, a plate-shaped methanogen representing a novel family, the Methanoplanaceae. Arch Microbiol 132:31 - 36

Williams WJ (1979) Handbook of anion determination. Butterworths, London, pp 570-572

Zillig W, Stetter KO, Wunderl S, Schulz W, Priess H, Scholz I, (1980) The Sulfolobus-“Caldariella" group: Taxonomy on the basis of the structure of DNA-dependent RNA polymerases. Arch Microbiol 125:259-269

Received November 28, 1988/Accepted January 16, 1989 